\title{
MODELING SOLAR ABSORPTION CHILLING SYSTEM WORKED BY FLAT PLATE COLLECTOR OR TRACKED CONCENTRATED PARABOLIC DISH
}

Mahmoud; R. K. ${ }^{3}$, Ghanem; T. $\mathbf{H}^{\mathbf{1}}$,

Al-Soaly, I. S. $A^{1}$ and A. M. El-Lithy ${ }^{2}$

ABSTRACT

The aim of the present study is to develop mathematical analysis for predicting the coefficient of performance of flat plate and concentrated parabolic dish solar collectors for driving absorption-chilling systems using water as heat exchange fluid, which is helpful in design, operation criterion, and for increasing the efficiency of research accomplishment. The prediction equation of the two studied chilling systems have coefficients of determinations ranged between 0.878, 0.875. It was also found the concentrated parabolic dish chilling system has highest values of the coefficient of performance. Linear relationships were justified for both flat plate solar collector and concentrated parabolic dish respectively with coefficient of determination of 0.9714 to 0.7866.

\section{INTRODUCTION}

I $\mathrm{n}$ Egypt, the amount of incident solar radiation per square meter range between 5.0 to $8.0 \mathrm{~kW}$.h per day with about 3500 sunshine hours per year, Sorensen (2003). Therefore, solar energy is a renewable major clean source of energy, which is alternative to using electricity and fossil fuels. Combined chilling system or absorption refrigeration is that uses three thermodynamic substances to accomplish cooling effect namely: ammonia (refrigerant), water (absorbent) and helium. Ammonia is used as a refrigerant as it is easily available and can produce better cooling effect. Helium is used to reduce the partial pressure of ammonia vapor in the evaporator, so that more ammonia evaporates yielding more cooling effect. For operating this system, no moving parts is required, heat of aqua ammonia can be added through a generator. Due to these characterized aspects, generator heat can be added through a solar collector using an auxiliary heat exchanger.

\footnotetext{
.$^{1}$ Prof. of Agric. Eng. Dep., Fac. of Ag. Eng., Cairo, Al-Azhar Univ.

2 Prof., Agric. Eng. Dep., Fac. of Ag. Eng., AL-Azhar U. Assiut. Univ.

${ }^{3}$ Assist. Lecturer of. Agric. Eng. Dep., Fac. of Ag. Eng., AL-Azhar U. Assiut. Univ.
} 
Most conventional refrigeration systems is operated with electricity. However, there are regions where it is difficult or not cost efficient to provide electric service. In addition, the cost of generating electricity is high, both economically and ecologically. Lingeswaran and Hemalatha (2014) and Karthik(2014). On the other hand, absorption refrigeration cycle used in the present work is ecofriendly, has no mechanical moving components and plays an important role in maintaining agricultural production quantity and quality. Due to lack or absence of postharvest treatments specifically precooling and storage, experts evaluate $15.27 \%$ of fruit and $45.58 \%$ of vegetable drops in marketing value. Egypt productions of fruits and vegetables were estimated by 11,750,975 and 21,236,320 billion of Egyptian pounds annually, as stated in the MALR and E. A. S (2011). Tyagi et al. (2012) and Selvakumar and Barshilia (2012) showed that, the solar collector can be classified to non-concentrated and concentrated, it may be of the following types; flat plate collector, evacuated tube, parabolic trough reflector, parabolic dish reflector and linear fresnel reflector. Kalogirou et al. (1994) reported that, concentrating systems exhibit certain advantages as compared with the conventional flat plate type. Biari (1990) stated that, the concentrator systems will not work efficiently without sun tracking, so at least single axis tracking is required; this is as a result of the continuous changing of sun position with respect to time of the day. He reported that the amount of solar energy captured by a tilted collector could be increased by more than $40 \%$ by adjusting the tilt angle. Duffie and Beckman (1991) mentioned that flat plate collectors utilize both diffuse and direct radiations, therefore they can be worked in cloudy or hazy conditions, however, they might not be able to generate a desired temperature in these conditions. The applications that flat plate collectors can be used in provision of hot water, space heating, air conditioning, and industrial process heating. The main drawbacks of these collectors are their low efficiencies and low generating temperatures. In order to increase the research efficiency dimensional analysis was used for predicting equations for refrigerators coefficient of performance. Zohar et al. (2005) designed constructed a thermodynamic model for an ammoniawater diffusion absorption refrigeration cycle with hydrogen and helium as the auxiliary inert gas. They found that helium was superior to hydrogen as 
the inert gas: the COP of the system with helium was higher than by up to $40 \%$ than a cycle working with hydrogen. Jakob and Eicker (2002) mentioned that sub-zero temperatures were attained in the evaporator during trial runs. The system operated on a $38 \%$ solution of aqua-ammonia with helium as auxiliary gas and was powered indirectly by a fluid circuit heated in compound parabolic concentrating collectors. The simulated performance value for COP of 0.53 was calculated without extensive conservation equations. The prototype's components were not thermally insulated and no rectifier was used, hence the COP was found to never exceed 0.15 in practice.

The purpose of the present study is to develop a fully self-combined solar powered chilling system for rural areas which have no access to electricity service and also for encountering the dramatically cost rises of electricity and traditional power sources for both home, agricultural and industrial precooling, refrigeration and storage manipulation. The main objective of the present study were:

1- In order to increase the research efficiency dimensional analysis was used for predicting equations for refrigerators coefficient of performance.

2- Comparing the coefficient of performance of the combined solar chilling system using a flat plate solar collector with an concentrating one using water substance as a heat exchange fluid, Mstatic 2.1 (2010) was used for this purposes

\section{THEORETICAL APPROACH}

In Present work, dimensional analysis is based on the following assumptions:

1-The system is consisted of two separate thermodynamic cycles, these two cycles are interacted, and exchanged heat in counter current heat exchanger.

2-Heat is instantaneously exchanged.

3-Tow dimensional flow rate .

The first step in the similitude application is to define the most associated variable affecting the investigated phenomena. The following are the pertinent and independent variables considered to affect the coefficient of performance chilling system. Their units and dimensions are as follows: 
PROCESS ENGINEERING

\begin{tabular}{|l|l|l|l|l|}
\hline NO & Symbol & Description & Dimension & Units \\
\hline 1 & $\mathrm{COP}$ & The coefficient of Performance & dimensionless & $\ldots \ldots$ \\
\hline 2 & $\mathrm{Qi}$ & Solar energy available & $\mathrm{W}$ & $\mathrm{H} \mathrm{t}^{-1}$ \\
\hline 3 & $\mathrm{U}$ & Overall heat transfer coefficient & $\mathrm{W} \mathrm{m}{ }^{-2} \mathrm{C}^{-1}$ & $\mathrm{HL}^{-2} \mathrm{t}^{-1} \Theta^{-1}$ \\
\hline 4 & $\Delta \mathrm{T}$ & Different temperature inlet and outlet & ${ }^{\circ} \mathrm{C}$ & $\Theta$ \\
\hline 5 & $\mathrm{Mg}$ & Mass flow ammonia -water & $\mathrm{Kg} \mathrm{s}^{-1}$ & $\mathrm{M} \mathrm{t}^{-1}$ \\
\hline 6 & $\mathrm{~A}$ & Surface area tube exchanger & $\mathrm{m}^{2}$ & $\mathrm{~L}^{2}$ \\
\hline 7 & $\mathrm{Cp}$ & Specific heat of ammonia -water & $\mathrm{KJ} \mathrm{Kg}^{-1} \mathrm{C}^{-1}$ & $\mathrm{H} \mathrm{M}^{-1} \Theta^{-1}$ \\
\hline 8 & $\mathrm{Mp}$ & Mass product & $\mathrm{Kg}$ & $\mathrm{M}$ \\
\hline
\end{tabular}

The general relationship for the coefficient of performance solar chilling system as a function of the associated independent variables can be expressed as:

$$
C O P=f(Q i, U, \Delta T, M g, A, c p, m p)
$$

According to the Buckingham pi-theorem, the number of dimensionless and independent quantities required to express a relationship among variables in any phenomenon is equal to the number of quantities involved, minus the number of dimensions of those quantities Singh and Heldman(2014). In the present study eight quantities with five dimensions is involved. So, three dimensionless groups can be formed. The following dimensionless groups are obtained:

$$
\begin{aligned}
& \pi_{1}=\operatorname{COP} \ldots \ldots \ldots \ldots \\
& \pi_{2}=\frac{M_{g} c p \Delta T}{I A}=\frac{Q_{g}}{Q_{i}} \ldots
\end{aligned}
$$

$\boldsymbol{\pi}_{2}$ can be defined as a generator heating group .

$\pi_{3}=\frac{U A}{M_{g} c p}=\frac{U A}{C \min }$

$\boldsymbol{\pi}_{\mathbf{3}}$ can be defined as a bubble pump working group .

Accordingly, the prediction equation can be reduced to the form:

$C O P=f\left(\frac{Q_{g}}{Q_{i}}, \frac{U A}{C \min }\right)$

Where NTU is the number of transfer units previously defined . 
$C O P=f\left(\frac{Q_{g}}{Q_{i}}, N T U\right)$

Experiments were conducted to determine the proportional constant.

\section{MATERIAL AND METHODS}

This research was carried out to develop a fully combined solar powered chilling system for encountering the dramatically cost raised of electricity and traditional power source for both home, agricultural, and industrial precooling, refrigeration and storage manipulation. Diffusion absorption refrigeration system (DARS) has been constructed, developed, and tested in Sohag Governorate, Egypt. Latitude 26.556 and longitude 31.655, with hourly solar intensity $8 \mathrm{~kW} . \mathrm{h} / \mathrm{m}^{2}$ per day or maximum Egyptian solar intensity for solar declination angle of $45^{\circ}$. Performance test were conducted using two alternatives as a heating source namely: flat plate collector or parabolic dish. The chilling system was consisted of two main closed and separated cycles i.e solar heating thermodynamic cycle and chilling cycle. The first cycle was used instead of the compressor conventionally used in traditional artificial refrigerators for driving the bubble pump and was used for heating a thermodynamic fluid through a heat exchanger as a generator. So, this research was extended to include:

\section{Refrigeration system powered by a solar flat-plate collector FPC or PD}

The diffusion absorption refrigeration system working by flat plate collector or parabolic dish are shown in Fig. (1), (2) FPC cooling system used the solar diffusion absorption refrigeration system used in the experimental part is consisted of the following two main separate closed thermodynamic cycles:

1- Solar heating thermodynamic cycle that constructed of solar heater or solar collector flat plate collector, pump and heat exchanger.

2- Refrigerator consisted of generator, condenser, evaporator, absorber cold chamber.

3- Solar heating thermodynamic cycle for PD is constructed of solar heater or solar parabolic tracking dish, Photovoltaic panel, control charger, and battery for system control an actuator and heat exchanger. 


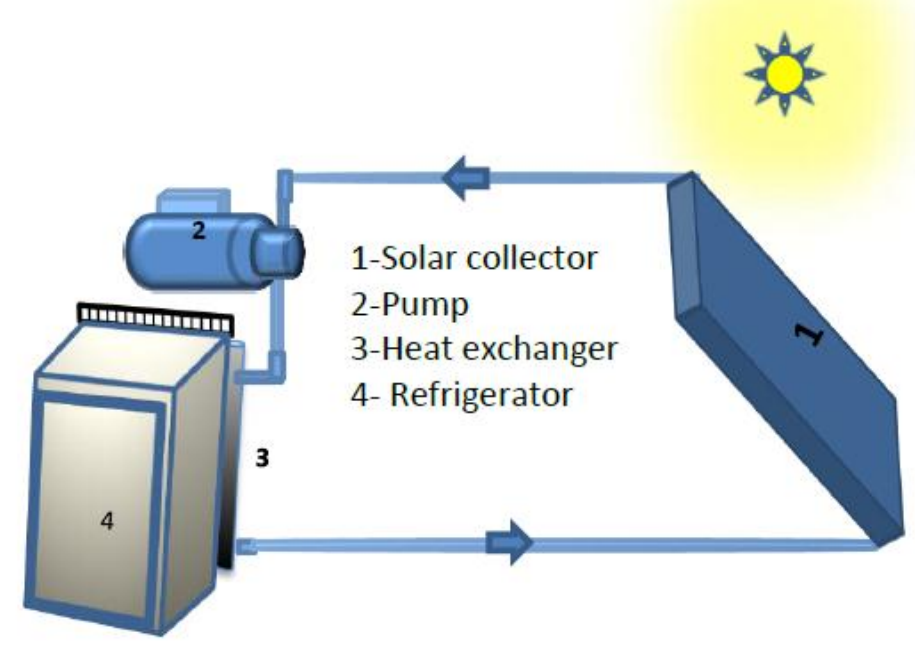

Fig. (1): Experimental setup of the FPC.

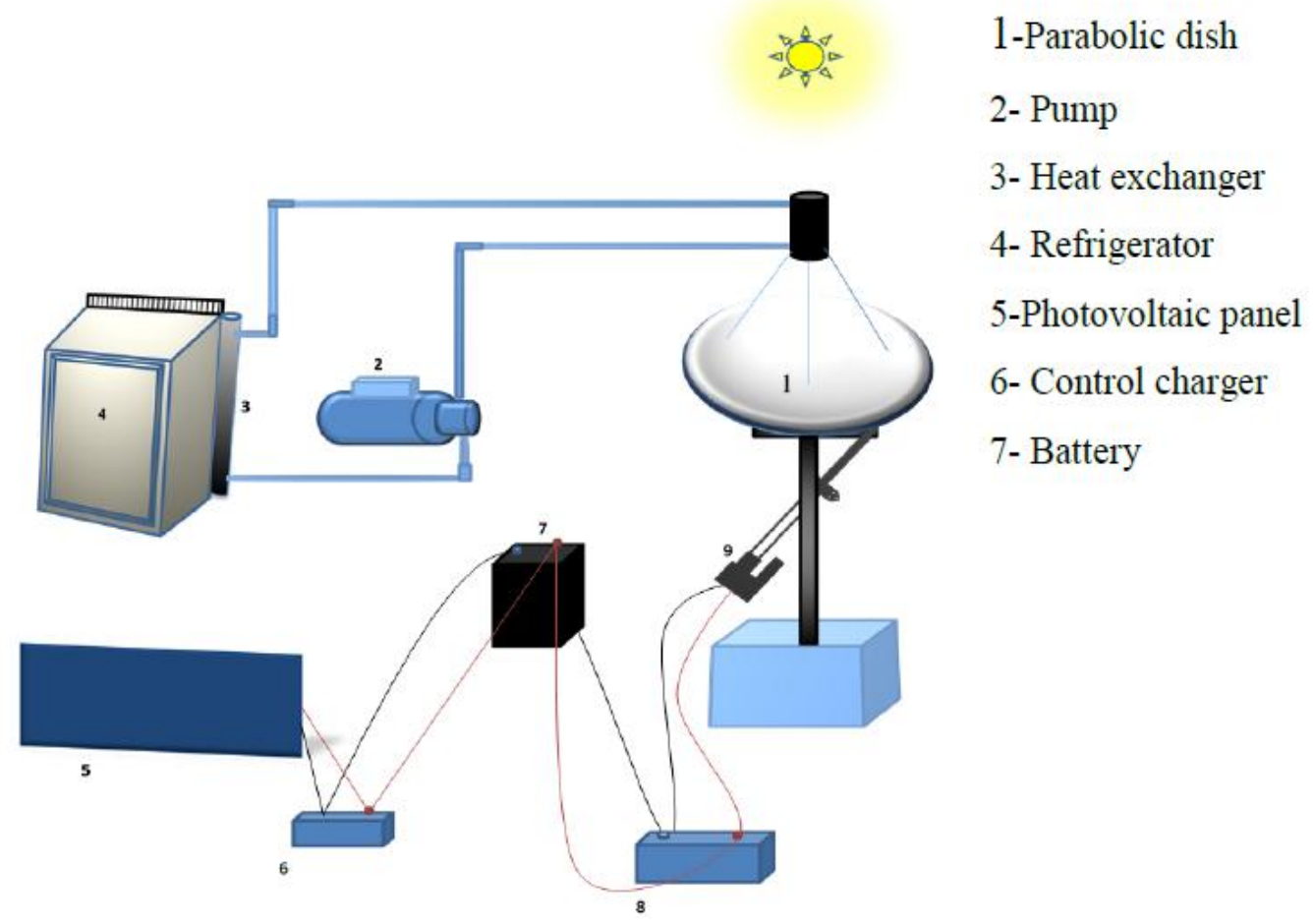

Fig. (2): Experimental setup of the PD.

\section{Solar tracker structure}

The following design criterion of the solar tracker structure were taken into account as reported by Biari (1990): (1) the receiver (2) the receiver support(3) the mass of the dish (4) the base support (5) the linear actuator 
(6) the support dish. Thus, the total mass of the system is $46 \mathrm{~kg}$ so the system weight is approximately $460 \mathrm{~N}$, as shown in Fig.(3).

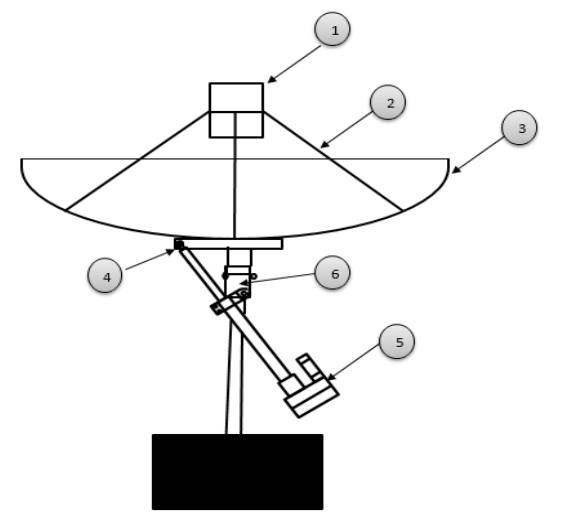

Fig.(3): Solar tracker structure .

Solar parabolic dish is directed toward the sun automatically with tracking control system using tree LDR and relays.

\section{Measuring instruments}

\section{Solar intensity device}

A black and white pyranometer designed, constructed tested by Ghanem (1989) and calibrated in the Solar Energy Department, National Research Center (NRC), Giza, Egypt .It was used for measuring solar intensity in W/ $\mathrm{m}^{2}$.

\section{Temperature devices.}

System temperatures were recorded by a digital thermometer and the different measuring points of the prototype using thermocouple type $\mathrm{K}$, of a range from -200 to $1250{ }^{\circ} \mathrm{C}$, with an accuracy of $\pm 1 \%+3$.

\section{Anemometer}

The anemometer was used for measuring air speed in $\mathrm{m} / \mathrm{s}$, The anemometer is model AN100 and made in U.S.A. of measuring range: $0.4-30 \mathrm{~m} / \mathrm{s}$ resolution $0.01 \mathrm{~m} / \mathrm{s}$ accuracy $\pm(3 \%+0.20 \mathrm{~m} / \mathrm{s})$.

\section{METHODS}

\section{Flat plate collector efficiency calculations}

In present study one dimensional heat flow equation is consided the governing equations of the collector system according to Fabio, (2008), Duffie and Beckman (2013) were used as follows: 


$$
\mathrm{Q}_{\mathrm{i}}=\mathrm{I} \mathrm{A}
$$

Where Qi is the absorbed solar energy $\mathrm{kJ}$, A is surface collector area $\mathrm{m}^{2}$, I is the intensity of solar radiation $\mathrm{W} / \mathrm{m}^{2}, \tau_{\mathrm{g}}$ is the transmittance and $\propto$ : is the absorption of plate collector.

$$
\mathrm{Q}_{\mathrm{i}}=\mathrm{I} \tau \propto \mathrm{A}
$$

$$
Q_{L}=U_{L} A\left(T_{p}-T_{a b}\right)
$$

Where $Q_{L}$ The rate of heat loss kJ,$T_{a b}=$ ambient temperature $\left({ }^{\circ} \mathrm{C}\right)$ and $\mathrm{Tp}$ $=$ mean plate temperature $\left({ }^{\circ} \mathrm{C}\right)$

The overall heat transfer coefficient of the collector $\boldsymbol{U}_{\boldsymbol{L}}$ is expressed by

$$
U_{L}=U_{T}+U_{B}+U_{S}
$$

Where $U_{T}, U_{B}$ and $U_{S}$ are the heat losses coefficients of the top, bottom and sides of the collector, respectively. Since $U_{S}$ is too small it can be neglected (Qasem and El-Shaarawi, 2015) $U_{T}$ is calculated according to Duffie and Beckman, 2013.

$$
U_{T}=\left[\frac{N g}{\frac{C}{T_{p}}\left[\frac{T_{p}-T_{a b}}{N g+f}\right]^{e}}+\frac{1}{h_{w}}\right]^{-1}+\left[\frac{\delta\left(T_{p}+T_{a b}\right)\left(T_{p}^{2}+T_{a b}^{2}\right)}{\left[\left(\varepsilon_{p}+0.0 .0059 N g h_{w}\right)^{-1}+\frac{2 N g+f-1+0.133 \varepsilon_{p}}{\varepsilon_{g}}-N g\right]}\right] \ldots
$$

$\mathrm{Ng}=$ number of glass covers,$\varepsilon_{p}=$ emittence of plate and $\delta=$ StefanBoltzman constant $\left(5.6704 \times 10^{-8} \mathrm{~kW} / \mathrm{m}^{2}{ }^{\circ} \mathrm{C}^{4}\right)$,

$\boldsymbol{f}=\left(1+0.089 \mathrm{hw}-0.1166 \mathrm{~h}_{\mathrm{w}} \varepsilon_{\mathrm{p}}\right)\left(1+0.07866 \mathrm{~N}_{\mathrm{g}}\right)$

$C=520\left(1-0.000051 \beta^{2}\right)$ for $0^{\circ}<\beta<70^{\circ} ;$ for $70^{\circ}<\beta<90^{\circ}$, use $\beta=70^{\circ}$ $\boldsymbol{e}=0.430\left(1-100 / \mathrm{T}_{\mathrm{p}}\right)$

$h_{w}=5.7+3.8 \mathrm{~V}$ when the wind speed equal to $5 \mathrm{~m} / \mathrm{s}$ and when it was more than $5 \mathrm{~m} / \mathrm{s}$ the following equation can be used $h_{w}=7.44(v)^{0.8}$ The back losses coefficient $U_{B}$ depends on the insulation material and its thickness which can be evaluated by:

$$
U_{B}=\frac{K_{s}}{L_{S}}
$$

$\mathrm{Ks}$ : thermal conductivity of the insulation material. $\mathrm{W} / \mathrm{m} .{ }^{\circ} \mathrm{C}$ $L_{s}$ : the thickness of the insulation material, $\mathrm{m}$ Thus, the rate of useful energy extracted by the collector $\boldsymbol{Q}_{\boldsymbol{c}}$ expressed as a rate of extraction under steady state conditions is equal amount lost by the collector to its surroundings subtracted form the rate of useful energy absorbed by the collector, that can be expressed as follows: 


$$
\begin{aligned}
Q_{c} & =Q_{i}-Q_{L} \ldots \ldots \ldots \ldots \ldots \ldots \\
& =I \tau \propto A-U_{L} A\left(T_{p}-T_{a}\right)
\end{aligned}
$$

The collector efficiency $\eta$ is defined as the ratio of the useful energy gain $\mathrm{Q}_{\mathrm{c}}$ to the incident solar energy over a particular time period:

$$
\eta=\frac{\int Q_{c} d t}{A \int I d t}
$$

The instantaneous thermal efficiency of the collector is:

$$
\eta=\frac{Q_{c}}{I A}=\frac{Q_{c}}{Q_{i}}
$$

\section{2 .Collector PD efficiency calculations}

The geometrical parameters of the parabola are given by the following equations William and Raymond, (1985): The focal length of parabola is given by:

$$
f=\frac{D^{2}}{16 h}
$$

Geometric concentration ratio $(\mathrm{CRg})$ : relation between the aperture area of the collector (Aap) and the receiver area $($ Arec $)$ :

$$
\mathrm{CR}_{\mathrm{g}}=\frac{\mathrm{A}_{\mathrm{ap}}}{\mathrm{A}_{\mathrm{rec}}} \ldots
$$

Thermal efficiency of the parabolic dish collector is defined as the ratio of the useful energy $\boldsymbol{Q}_{c}$ delivered to the working fluid to the energy incident on the concentrator aperture as follows:

$$
\begin{aligned}
\eta_{\mathrm{c}} & =\frac{\mathrm{Q}_{\mathrm{c}}}{\mathrm{Q}_{\mathrm{i}}} \ldots \ldots . . \\
\mathrm{Q}_{\mathrm{i}} & =\mathrm{I}_{\mathrm{b}} \cdot \mathrm{A}_{\mathrm{ap}}
\end{aligned}
$$

Where $I_{b}$ The direct normal isolation $\mathrm{W} / \mathrm{m}^{2}$

- Useful heat

$$
\mathrm{Q}_{\mathrm{c}}=\mathrm{Q}_{\mathrm{o}}-Q_{l}
$$

The optical energy absorbed $Q_{0}$ by the receiver is obtained by Thakkar (2015):

$$
\begin{array}{r}
\mathrm{Q}_{\mathrm{o}}=\mathrm{A}_{\mathrm{ap}} \cdot \eta_{\mathrm{o}} \cdot \mathrm{I}_{\mathrm{b}} \ldots \ldots \\
Q_{l}=U_{L}\left(T_{p}-T_{a b}\right) A_{r e c}
\end{array}
$$

\section{Optical efficiency $\eta_{o}$}

The optical efficiency of the collector is given by the following equation:

$$
\eta_{\mathrm{o}}=\rho_{\mathrm{s}} \cdot \tau_{\mathrm{g}} \cdot \alpha_{\mathrm{r}} \cdot S .
$$


$\rho_{s}=0.92$ is the collector spectrum reflectance , $\alpha_{r}=0.88$ is the absorptivity of the receiver $\quad \mathrm{S}=$ receiver shading factor, $\tau_{\mathrm{g}}$ is the transmittance of glass envelope covering the receiver (if present)

\section{- Thermal efficiency}

The thermal efficiency in solar dish concentrators can be defined in two different ways

Gorjan et al (2013):

Thermal collector efficiency: ratio between the useful energy delivered to the fluid and the total energy aperture by the reflective surface, as expressed by Eq. (24).

$\eta_{\text {concentrator }}=\frac{Q_{u}}{A_{a p} I_{b}}=\frac{Q_{u}}{Q_{i}}$

Thermal receiver efficiency: ratio between the useful energy delivered from the receiver to the fluid and the energy falling on the receiver, Eq. (25).

$\eta_{\text {receiver }}=\frac{Q_{u}}{A_{a p} I_{b} \eta_{o}}$

\section{Refrigeration load}

The refrigeration load is the rate of heat energy removal from a given space (or object) in order to lower the temperature of space to a desired level ( Paul Singh and Dennis 2014) The refrigeration load of any product can be determined as follow:

- Heat removed from cold room.

$$
Q_{r}=\frac{m p c p(t a b-t c b)}{t}
$$

Where Tcb temperature of inside the refrigerator ${ }^{\circ} \mathrm{C}, \mathrm{Cp}$ : is the specific heat of load material $\mathrm{kj} / \mathrm{kg}$ oc , Ac surface area of refrigeration unit $\mathrm{m}^{2}$ and Hresp : heat respiration $\mathrm{W} / \mathrm{kg}$

\section{- Heat leakage (Conduction through)}

\section{- Heat respiration}

$$
Q_{L}=U_{l} A_{c}\left(t_{a b}-t_{c b}\right)
$$

$$
\begin{aligned}
\text { Qresp } & =m p \text { Hresp } \ldots \ldots \\
Q_{\text {Ref.load }} & =Q_{r}+Q L+Q r p
\end{aligned}
$$

Where $\mathrm{Q}_{\text {Ref. load }}$ : is required The refrigeration load $\mathrm{kW}$ and $\mathrm{QL}$ : rate of heat transmitted through wall, $\mathrm{kW}$ 


\section{4 .Performance of the solar refrigerator}

\section{- Actual coefficient of performance}

Actual coefficient of performance can be determined experimentally. The performance of the solar refrigerator is defined as the ratio of cooling obtainable to the amount of solar energy absorbed by the solar collector Rayan et al. (1985)

$$
(\mathrm{COP})_{\text {actual }}=\frac{\mathrm{Q}_{\text {Ref load }}}{\mathrm{Q}_{\mathrm{c}}} . .
$$

The following relations will exist between the actual coefficient of performance of the cycle and the coefficient of performance of the system, that are used for calculating $\pi_{1}$ :

$$
\begin{gathered}
(\mathrm{COP})_{\text {sys }}=(\mathrm{COP})_{\text {actual }} \quad \eta_{\mathrm{FPC}} \\
\text { Or } \\
(\mathrm{COP})_{\text {sys }}=(\mathrm{COP})_{\text {actual }} \quad \eta_{\mathrm{PD}} \cdots
\end{gathered}
$$

\section{Determining the flow rate of ammonia in the generator}

The flow rate of ammonia in the generator can be determined according to Ghassan et al.(2015) :

$$
\begin{gathered}
Q_{\text {Ref load }}=m_{e} \Delta h \ldots \ldots \\
M_{e}=1.15 m_{e} \ldots \ldots \ldots \ldots \\
M_{W E}=0.0029+0.1 M_{e} \\
M_{g}=M_{e}+M_{w e} \ldots \ldots \ldots \ldots
\end{gathered}
$$

Where $m_{e}$ : the flow rate of ammonia in the evaporator, $M_{e}$ : original mass refrigerant in solution, $\mathrm{M}_{\mathrm{wE}}$ : the flow rate of weak solution and $\mathrm{M}_{\mathrm{g}}$ : the flow rate solution in generator $\mathrm{kg} / \mathrm{s}$

\section{Analysis of heat exchangers}

In analyzing the counter current heat exchanger used in the present study according to Incroperal et al.(2007) :

- Log mean temperature difference (LMTD).

The heat transfer process could be derived from Equation:

$$
Q_{g}=U A \Delta T_{m}
$$

Where

$$
Q_{g}=M_{g} C p\left(T_{c o}-T_{c i}\right) \ldots
$$




$$
\Delta T_{m}=\frac{\left(T_{h i}-T_{c o}\right)-\left(T_{h o}-T_{c i}\right)}{\ln \frac{T_{h i}-T_{c o}}{T_{h o}-T_{c i}}}
$$

For determining $\pi_{3}$ the following eqn. is used :

$$
N T U=\frac{A U}{C \min }
$$

For determining $\pi_{2}$ the following eqn. is used :

$\pi_{2}=\frac{Q_{g}}{Q_{i}}=\frac{M_{g} C p\left(T_{c o}-T_{c i}\right)}{Q_{i}}$

Where $Q_{i}=I A$

\section{RESULTS AND DISCUSSIONS}

Dimensional analysis was used for predicting COP of FPC and PD with water as working heating fluid, which can be helpful in design , operation criterion and for increasing the efficiency of research accomplishment. Theoretical approach shows that the following prediction equation is valid for both FPC and PD respectively for predicting COP.

$\pi_{1}=f\left(\pi_{2} \cdot \pi_{3}\right) \ldots \ldots \ldots$
$C O P=f\left(\frac{Q_{g}}{Q_{i}} . N T U\right)$

The relationship between $\pi_{1}=C O P$ and $\pi_{2}=\frac{Q_{g}}{Q_{i}}$ when $\pi_{3}=\frac{A U}{C \min }$ varied satisfied linear equation and agreed with Suresh and Mani (2013) of the form:

$\pi_{1}=a \pi_{2}$

$C O P=a\left(\frac{Q_{g}}{Q_{i}}\right)$

Table (1) showed the parameter "a" and the coefficient of determinations for both FPC and PD in the counter current heat exchanger respectively. Figs (5a)and(5b) showed the relationship between $\pi_{1}$ and $\pi_{2}$ at constant values of $\pi_{3}$.It is clear that as $\pi_{2}$ increases $\pi_{1}$ increases when $\pi_{3}$ increases from 1.475 to 1.533 these $\pi_{3}$ decreased to 1.519 . This result may be interpreted by increasing ammonia bubble or flow rate that increasing the COP of the chilling system. Table (1) and figs (6a) and (6b) showed linear relationships justified for and parameter (a) with coefficient of determination of 0.9714 and 0.7866 for both FPC and PD using water as heat exchange fluid respectively. 
Table (1) Showed the parameter "a" and coefficient of determinations for both FPC and PD in the counter current heat exchanger

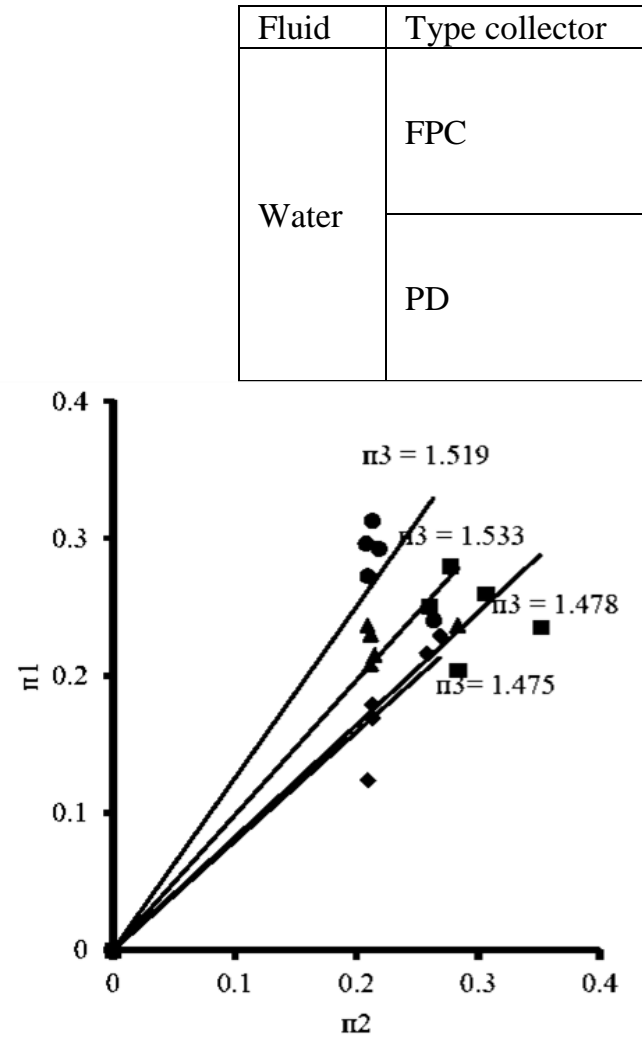

Fig. (a)

\begin{tabular}{|l|l|}
$\mathrm{A}$ & $\mathrm{R}^{2}$ \\
\hline 0.793 & 0.934 \\
\hline 0.8198 & 0.854 \\
\hline 0.822 & 0.829 \\
\hline 0.9626 & 0.925 \\
\hline 0.6058 & 0.88 \\
\hline 0.936 & 0.82 \\
\hline 0.988 & 0.977 \\
\hline 1.207 & 0.976 \\
\hline
\end{tabular}

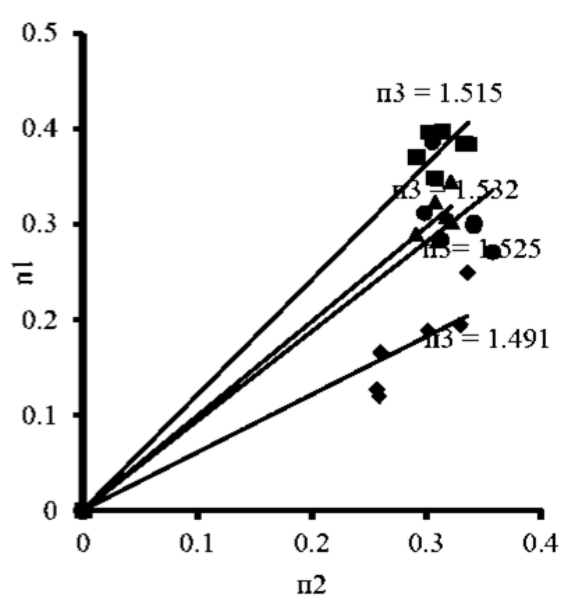

Fig. (b)

Fig. (5): The relationship between parameter $\pi_{1}=\operatorname{COP}$ and $\pi_{2}=\frac{Q_{g}}{Q_{i}}$ at constant $\pi_{3}=N T U$ for chiller driven by FPC and PD

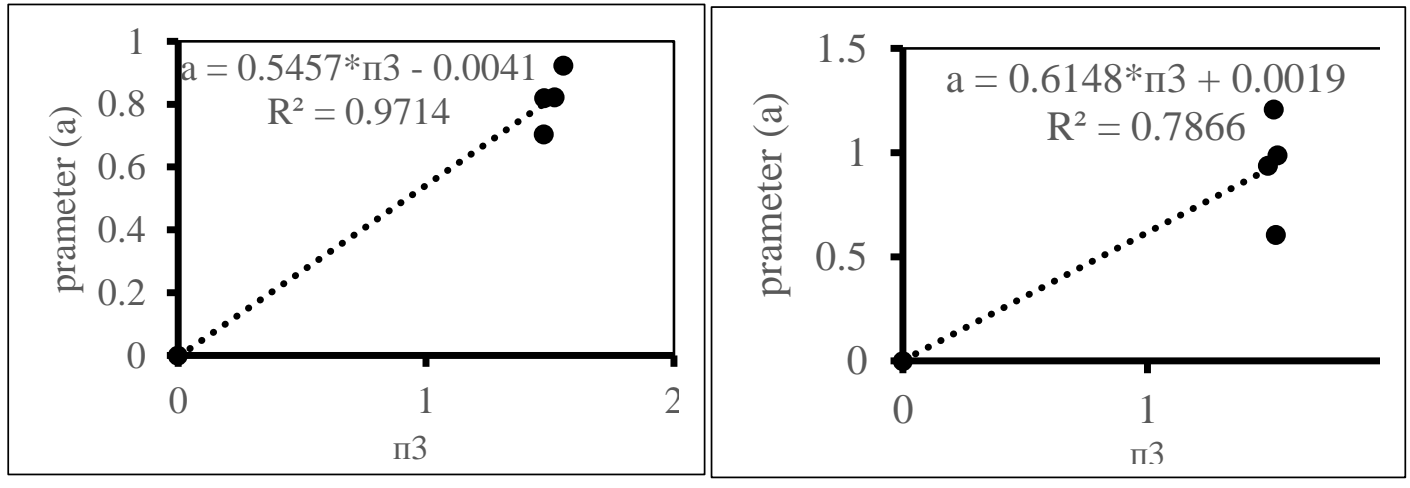

Fig. (6): The relationship between parameter " $a$ " and $\pi_{3}=\mathrm{NTU}$ for chiller driven by FPC and PD solar energy. 
The following equation is valid for both FPC, PD in the counter current heat exchanger respectively.

$a=C$ (п3) $+D$

The complete general predicted equation for COP of both FPC and PD.

$C O P=(C(\Pi 3)+D) * \Pi 2$

$C O P=(C * N T U+D) * \frac{Q g}{Q i}$

Values of constants C and D in previous equation for both FPC and PD were as follows:

\begin{tabular}{|l|l|l|}
\hline Fluid work & C & D \\
\hline FPC water & 0.5457 & -0.0041 \\
\hline PD water & 0.6148 & 0.0019 \\
\hline
\end{tabular}

Figs (7a) and (7b) showed the relationships between observed and predicted data using eqn. (49) for both FPC and PD respectively, it is clear that the prediction equation was reasonably accepted with coefficient of determination range 0.8786 to 0.8758 .

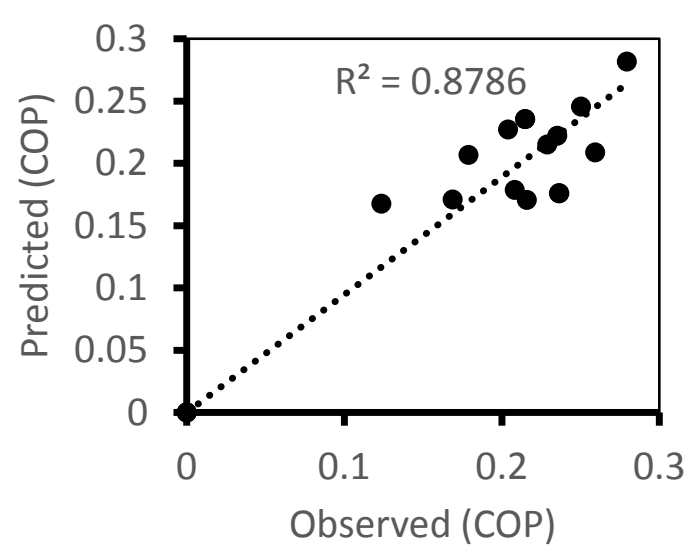

Fig.(a)

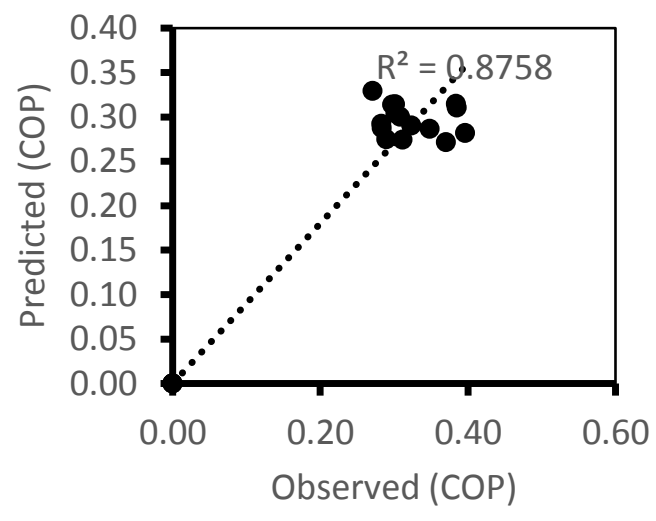

Fig.(b)

Fig. (7): Predicted and observed (COP) for chiller driven by FPC and PD solar energy. 
For comparing FPC and PD using the relationship between COP as affected by the heating group $\left(\pi_{2}=\frac{Q_{g}}{Q_{i}}\right)$ at constant values of bubble pump working group $\left(\pi_{3}=\frac{A U}{C \min }\right)$ with water as working heating fluid Fig.(8), clears that the COP increasing as the heating group increases. It is also clear that the chilling system using FPC has lowest values of PD for same studied conditions. Statistical analysis with $\mathrm{M}$ static 2.1 showed significant decrement For COP of FPC than PD, with average values of 0.186 and 0.211 respectively these results agreed with Kalogirou et al.(1994).

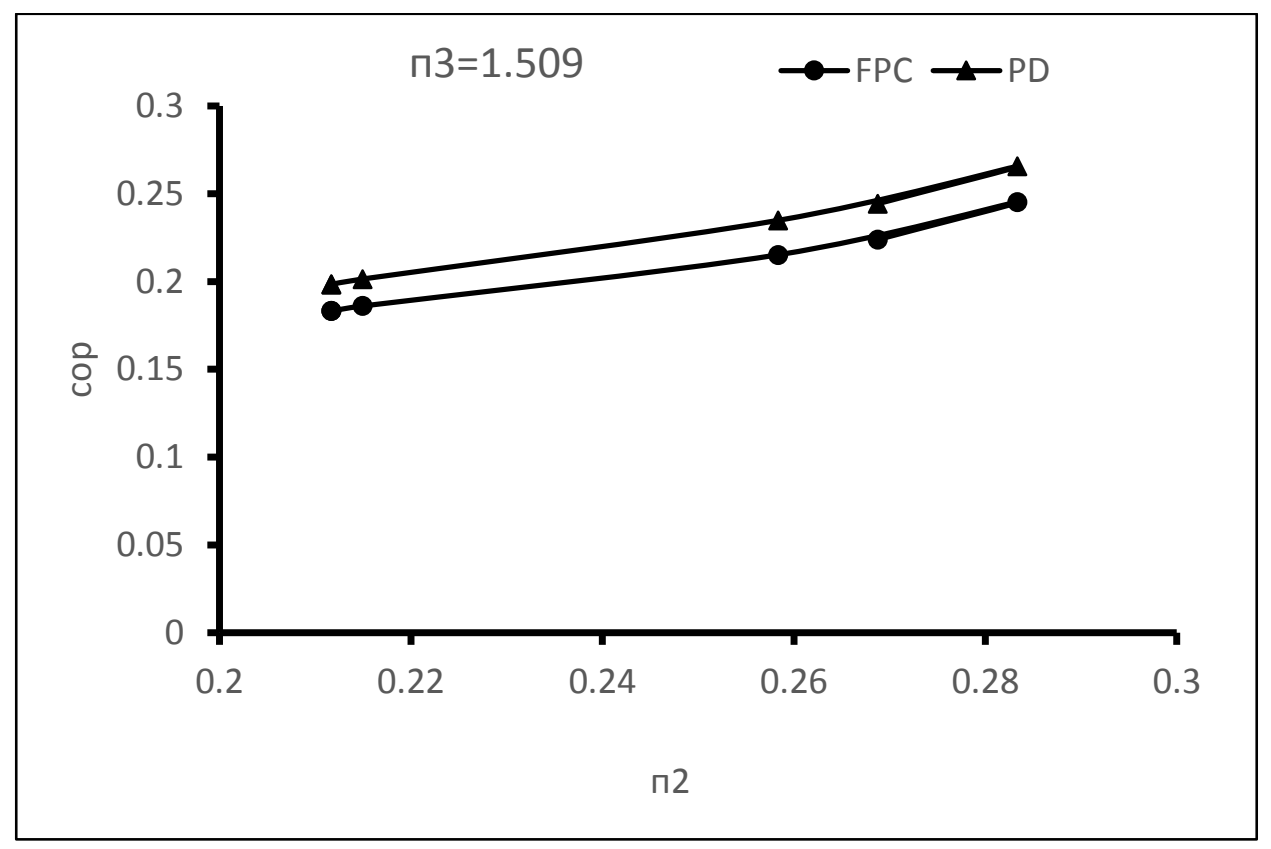

Fig. (8): Comparing the FDC and PD at constant $\pi_{3}=N T U$

\section{SUMMARY AND CONCLUSION}

The aim of the present study is to develop mathematical analysis for predicting the coefficient of performance of flat plate solar collector and concentrated parabolic dish collector for driving absorption-chilling system using water as heat exchange fluid heated by solar energy, which is helpful in design, operation criterion, and for increasing the efficiency of research accomplishment. 
In Present work, dimensional analysis is based on the following assumptions:

1-The system is consisted of two separate thermodynamic cycles, these two cycles are interacted, and exchanged heat in counter current heat exchanger.

2-Heat is instantaneously exchanged.

3-Tow dimensional flow rate.

From the present study we can concluded that:

1- The prediction equation of the two studied chilling systems have coefficients of determinations ranged between 0.878 and 0.875 respectively, the predicted equation were of the form:

$C O P=(C * N T U+D) * \frac{Q g}{Q i}$

Where COP is coefficient of performance dimensionless, C and D are functions of $\pi_{3}$ or $N T U=\frac{A U}{C \min }$ "bubble pump working group " which are linearly justified, these group is depending on the overall heat transfer coefficient related to minimum value of ammonia heat capacity which is essential for bubble pump operation that highly affecting the COP of the chilling system. $\pi_{2}=\frac{Q_{g}}{Q_{i}}$ "heating group" is the ratio between useful heat exchanged generator related to the available solar insolation.

2- Linear relationships were justified for both flat plate solar collector and concentrated parabolic dish respectively between "a" and "NTU" during prediction equation evaluation with coefficient of determination of 0.9714 to 0.7866 .

3- It was also found that the COP increasing as the heating group increases.

4- The concentrated parabolic dish chilling system has highest values of the coefficient of performance.

5- Statistical analysis showed significant decrement for COP of FPC than PD with average values of 0.186 and 0.211 respectively. 


\section{REFERENCES}

Bairi, A. (1990). Method of quick determination of the angle of slope and the orientation of solar collectors without a sun tracking system. Solar Wind Technol. 7, 327-330.

Duffie, J. A., and Beckman, W. A. (1991). Solar Engineering of Thermal Processes, Second Edition, John Willey \& Sons INC, chapt (6), p250.

Duffie, J. A., and Beckman, W. A. (2013). Solar engineering of thermal processes. John Wiley and Sons.

Fabio, Struckmann., (2008). Analysis of a flat-plate solar collector. Heat and Mass Transport, Project Report, $2008 M V K 160$.

Ghassan, A.H., Naif, K.A.,and Mohammed,A.M.(2015). Development of an Absorption Refrigeration System Powered by Solar Energy to Extract Fresh Water from Humid Air in Saudi Arabia. Global Journals Inc. (USA). Online ISSN: 2249-460x and Print ISSN: 0975$587 X$.

Incropera, D., \& Dewitt, D. P. Bergman and Lavine, (2007). Fundamentals of Heat and Mass Transfer.

Jakob, U., and Eicker, U. (2002). Solar cooling with diffusion absorption principle. (In Proceedings of the 7th World Renewable Energy Congress. WREC. p. 5.)

Kalogirou S., Eleftheriou P., Lloyd S., and Ward J. (1994). Design and performance characteristics of a parabolic-trough solar collector system. Appl Energy;47:341-54.

Lingeswaran, K., and Hemalatha, C. (2014). Experimental studies on solar powered diffusion absorption refrigerator. Middle-East J. Sci. Res, 20(7), 876-880.

Ministry of Agriculture Land Reclamation and Economic Affairs Sector., (2011). Bulletin farm income estimates., 20: 5-40.

Paul Singh, R. and R. Dennis (2014). Introduction to food Engineering. Fifth Edition page 500-501 
Qasem, N. A., and El-Shaarawi, M. A. (2015). Thermal analysis and modeling study of an activated carbon solar adsorption icemaker: Dhahran case study. Energy Conversion and Management, 100, 310323.

Rayan M.A, Desoky. A.A. and Osman. H.I. (1985) an investigation of domestic solar absorption refrigeration system. AESTC 1. pp. 49-59.

Selvakumar, N., and Barshilia, H.C. (2012). Review of physical vapor deposited (PVD) spectrally selective coatings for mid and hightemperature solarthermal applications. Solar Energy Materials \& Solar Cells, (98), pp.1-23. Available at http://www.sciencedirect.com/science/article/pii/S09270248110059 39.

Singh, R.P and Heldman, D.R(2014). Introduction to food Engineering. Academic press is an imprint of Elsevier pp.844-848

Sorensen, B. (2003). Renewable Energy Its physics, engineering, use, environmental impacts, economy and planning aspects, 3rd Elsevier Academic Press, Roskilde Univ., Energy \& Environment Group, Ins. 2, Denmark.

Suresh, M., and Mani, A. (2013). Heat and mass transfer studies on a compact bubble absorber in R134a-DMF solution based vapour absorption refrigeration system. International journal of refrigeration, 36(3), 1004-1014.

Tyagi, V. V., Kaushik, S. C., and Tyagi, S. K. (2012). Advancement in solar photovoltaic/thermal (PV/T) hybrid collector technology. Renewable and Sustainable Energy Reviews, 16(3), 1383-1398.

William, B. and Raymond, W. (1985). Solar energy fundamentals and design, John Wiley \& Sons, New York, USA.

Zohar, A., Jelinek, M., Levy, A., and Borde, I. (2005). Numerical investigation of a diffusion absorption refrigeration cycle. Int. J. Refrig. 8 (4): 515-525. 


\section{الملخص العربيى

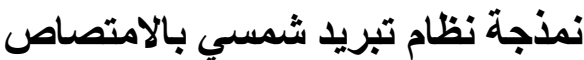

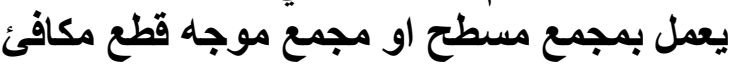

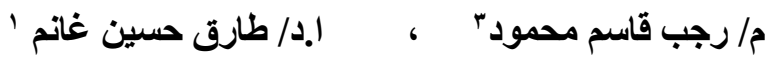

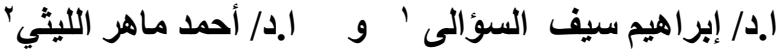

تعد مصر من الدول التي تقع في الحزام الثمسي و كمية الطاقة الثمسية الساقطة علي الأر اضي

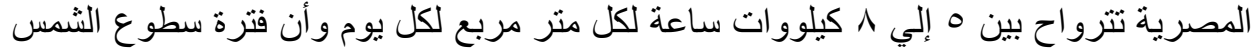
تقرب من · . هـ ساعة في السنة ما يجعل استخدام المجمعات الثمسية المسطحة او المركزة متاحا

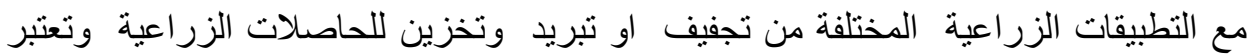

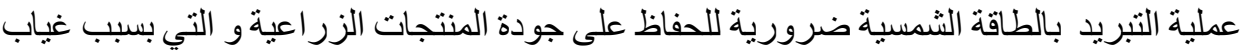

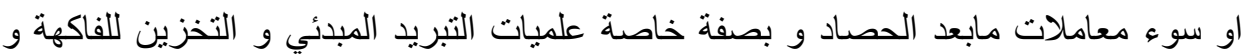

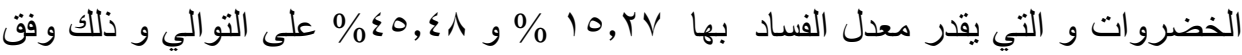

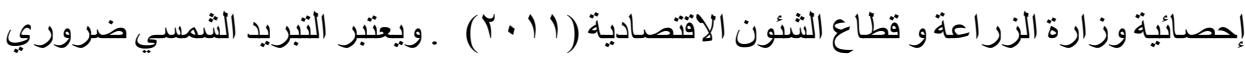

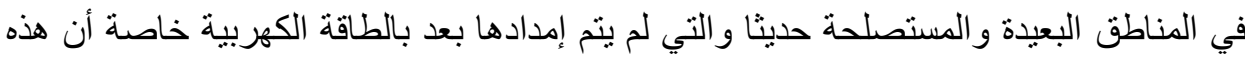
المناطق تتمتع بطاقة شمسية ذات كثافة عالية. إن تخزين الحاصلات التهات الزر اعية في ثناجات تبريد تعمل بالفريون يشكل حمل كهربي عالي و متذبذب خاصة أثناء فصل الصيف مما يؤدي إلي زيادة تكاليف استههلاك التخزين و تعرض الموتور بات إلي التلف و العطل بسبب الأحمال الكهربية العالية. لذلك فإن دائرة التبريد الثمسي بالامتصاص و التي تعمل بنظام خليط من ثلاثنة مو ائع (أمونيا-ماء-

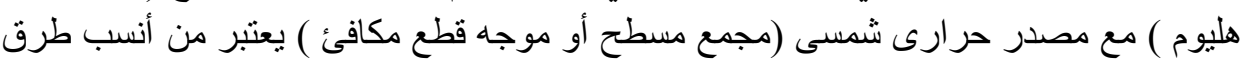

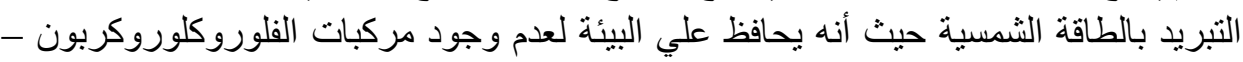

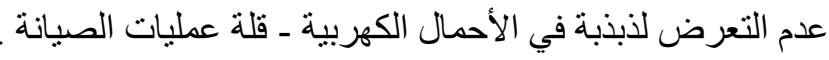
و يهدف البحث الى محاولة التوصل لنموذج رياضى للتنبؤ بمعامل أداء دورة التبريد مع مصدر مئه حرارى شمسى مجمع مسطح او موجه قطع مكافئ و قد بنى النموذج على أساس الافتر اضيات الأتية: ا ـ المنظومة نتكون من جزئين منفصلان بينهما منطقة تبادل حرارى تتمثل في مبادل

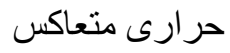

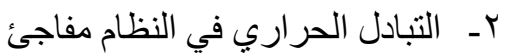

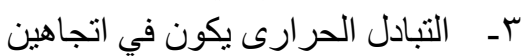
و يمكن لهذا النموذج ان يسهم في تطوير و تصميم و تشغيل و زيادة كفاءة استخدام الطاقة الثمسية و قد تم التوصل للاتي:

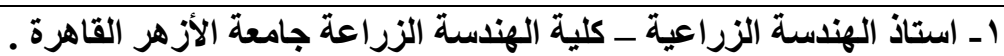

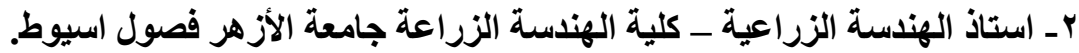
r- مدرس مساعد الهندسة الزراعية ـ كلية الهندسة الزراعة الزعة جامعة الازهر فصولة فيول أسيوط. 
1ـ نموذج رياضى باستخدام التحليل البعدى يوضح العلاقة بين (COP)ومجمو عة تدفق

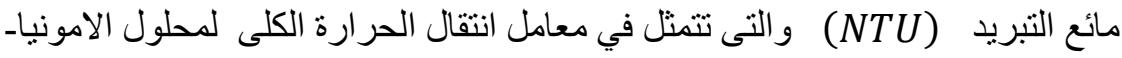

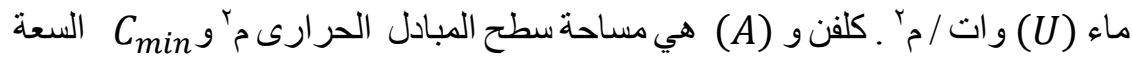

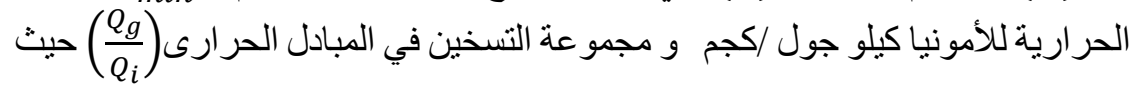

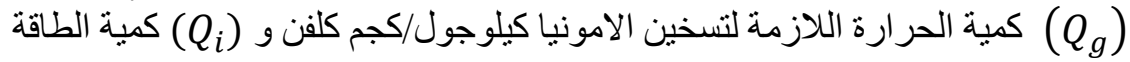
الثمسية المتاحة من مصدر النتخين كليوجول وكان النموذج على الصورة:

$$
C O P=(C * N T U+D) * \frac{Q g}{Q i}
$$

1- من خلال الدراسة التحليل اتضح ان العلاقة بين (a)و (NTU) الثناء عملية التنبؤ

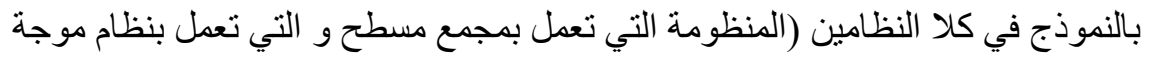

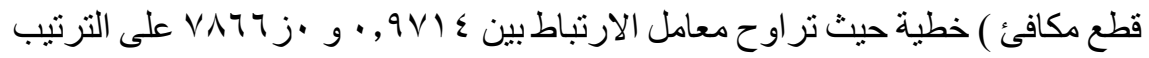

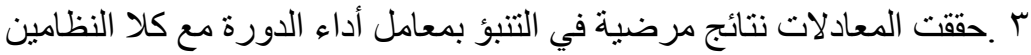

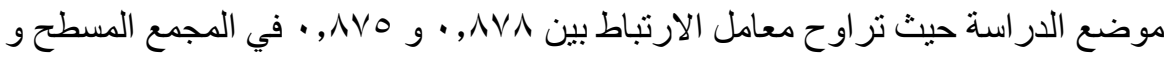

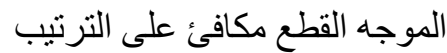

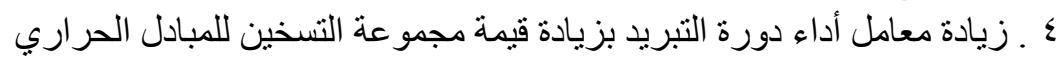

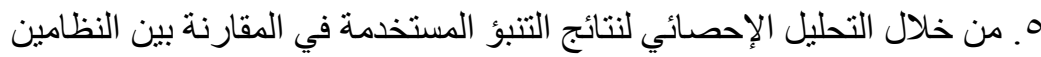

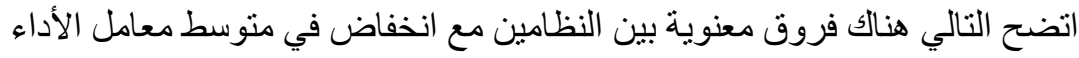

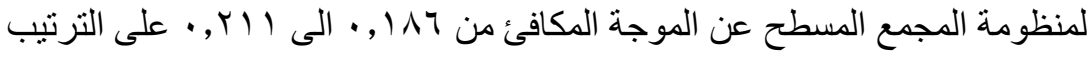

